\title{
Studies on the synthesis of 3-substituted benzo[b]furanes by intramolecular $S_{N} A r$ on 2-(2'-fluoroaryl)-2-(1-azolylmethyl)oxiranes
}

\author{
Antoni Santamaria, Marcial Moreno-Mañas, ${ }^{\dagger}$ and Roser Pleixats* \\ Chemistry Department, Universitat Autònoma de Barcelona, Cerdanyola del Vallès, 08193 \\ Barcelona, Spain \\ E-mail: roser.pleixats@uab.es
}

Dedicated to Professor Joan Bosch on the occasion of his $60^{\text {th }}$ anniversary

\begin{abstract}
The synthesis of substituted benzo[b]furan derivatives by an approach involving opening of 2(2'-halogenoaryl)oxiranes with base and subsequent cyclization of the alkoxide intermediate by an intramolecular $\mathrm{S}_{\mathrm{N}} \mathrm{Ar}$ reaction has been studied. Our results show that an azole moiety (imidazole, triazole) is required for the formation of benzo[b]furans. The negative charge in the intermediate carbanion is delocalized through the conjugated azole moiety (dipole stabilized side chain $\mathrm{N}-\mathrm{C} \alpha$ carbanions). Electron-withdrawing groups in the aromatic ring favour the intramolecular cyclization. This is the case when using 2'-fluoroaryl rather than 2'-chloroaryl groups, in accordance with the leaving-group ability of fluoro and chloro groups in the $\mathrm{S}_{\mathrm{N}} \mathrm{Ar}$ reaction. This methodology involves the formation of $\mathrm{O}(1)-\mathrm{C}(7 \mathrm{a})$ bond of benzo[b]furan in the cyclization step.
\end{abstract}

Keywords: Heterocycles, benzo[b]furans, intramolecular aromatic nucleophilic substitution, oxiranes, azole derivatives

\section{Introduction}

Several synthetic strategies can be found in the literature ${ }^{1}$ for the preparation of benzo[b]furans based on the building of the benzene ring from a properly substituted furan derivative or, much more often, on the building of the furan ring from substituted benzene derivatives. In the latter case, the formation of different bonds can be envisaged in the cyclization step: O-C2, C2-C3, C3-C3a and O1-C7a. The synthetic approach involving formation of the bond between the furane oxygen and the benzene ring is scarcely documented in the literature and no general method is available based on this approach.

${ }^{\dagger}$ Deceased on 20th february 2006 
On the other hand, in the course of an industrial research project aimed at the development of antifungal agents, we found an unexpected result when treating 2-(2'-fluoroaryl)-2-(1azolylmethyl)oxiranes with a non-nucleophilic base such as sodium tert-butoxide: the oxirane ring was opened by the effect of the base and the intermediate allylic alkoxide underwent spontaneous cyclization with displacement of a fluoro group to give the corresponding benzo[b]furane derivative. Presumably, the fluorine atom was activated as leaving group in a $\mathrm{S}_{\mathrm{N}} \mathrm{Ar}$ type process by the presence of a second fluoro group in the aromatic ring. Moreover, the negative charge in the intermediate carbanion was delocalized through the conjugated azole moiety (dipole stabilized side chain N-C $\alpha$ carbanions) ${ }^{2}$ (Scheme 1).
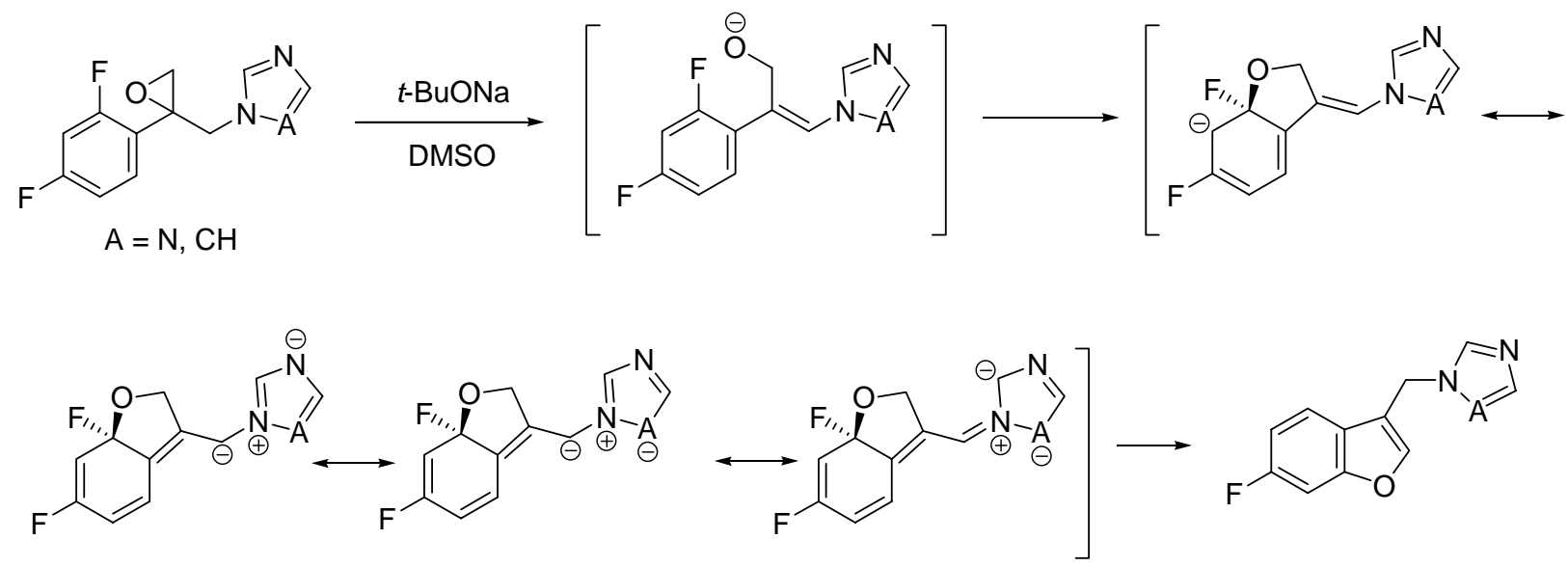

\section{Scheme 1}

We were interested in determining the scope of the synthesis of benzo[b]furans by the above described approach (formation of O-aromatic benzene carbon bond in the cyclization step). Several questions arise: a) is the presence of the azole moiety required for an effective cyclization?, b) what is the influence of additional electron-withdrawing substituents in the aromatic ring?, c) would chloro derivatives also lead to successful cyclization?. To answer these questions we prepared some 2-(2'-haloaryl)oxiranes and we tested the reaction of these substrates with base.

\section{Results and Discussion}

Preparation of substituted 3-(1H-1,2,4-triazol-1-ylmethyl)benzo[b]furans and 3-(1H-1imidazolylmethyl)benzo[b]furans

The proposed synthetic route leading to these 3-substituted benzo[b]furans 3 is outlined in Scheme 2, and involves the preparation of the required oxiranes $\mathbf{2}$ from the corresponding ketones 1. Base-induced opening of the epoxides 2 and subsequent cyclization would afford the 
heterocycles $\mathbf{3}$. Table 1 summarizes the substituents and the numbering of compounds 1-3 prepared.

Table 1. Substituents and numbering of compounds 1-3

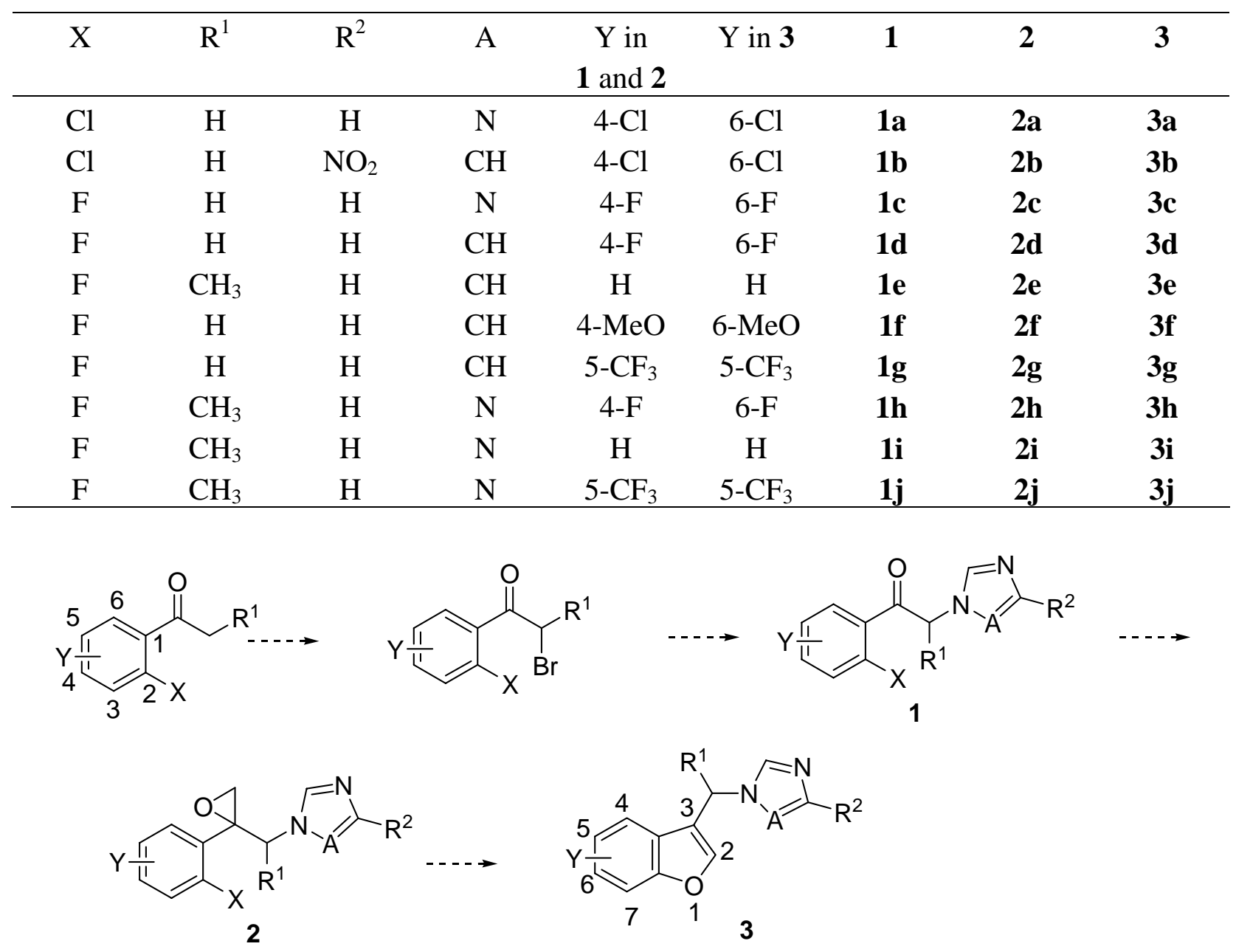

\section{Scheme 2}

Ketones 1 were prepared by standard methodologies summarized in Scheme 3. Method $\mathrm{A}^{3}$ was used for the synthesis of $\mathbf{1 a - b}$ and method $\mathrm{B}^{4}$ for the preparation of $\mathbf{1 d - g}$. Both procedures involve the $\alpha$-bromination of the starting ketone and the nucleophilic substitution of the bromo group by the corresponding azole. Compound 1a was also obtained from commercial 2-chloro-1(2',4'-dichlorophenyl)ethanone. HMBC (Heteronuclear Multiple Bond Connectivity) ${ }^{5}$ experiments confirmed the structure $\mathbf{1 b}$, the regioisomer containing a 4-nitro-1-imidazolyl group being selectively formed. Conditions B provided better yields than conditions A for ketones featuring an imidazole moiety. However, conditions B were less satisfactory for the triazole derivatives, by-products being obtained. Therefore, ketones $\mathbf{1 i}$-j bearing a triazole moiety were obtained by an alternative procedure (Method C), ${ }^{6}$ involving nucleophilic displacement by 4- 
amino-1,2,4-triazole and subsequent removal of the amino group via diazonium salt. Compound 1c was kindly provided by Ferrer Internacional S.A. Ketone $\mathbf{1 h}$ was prepared from $\mathbf{1 c}$ in modest yield (26\%) by treatment with methyl iodide in THF in the presence of sodium hydride.

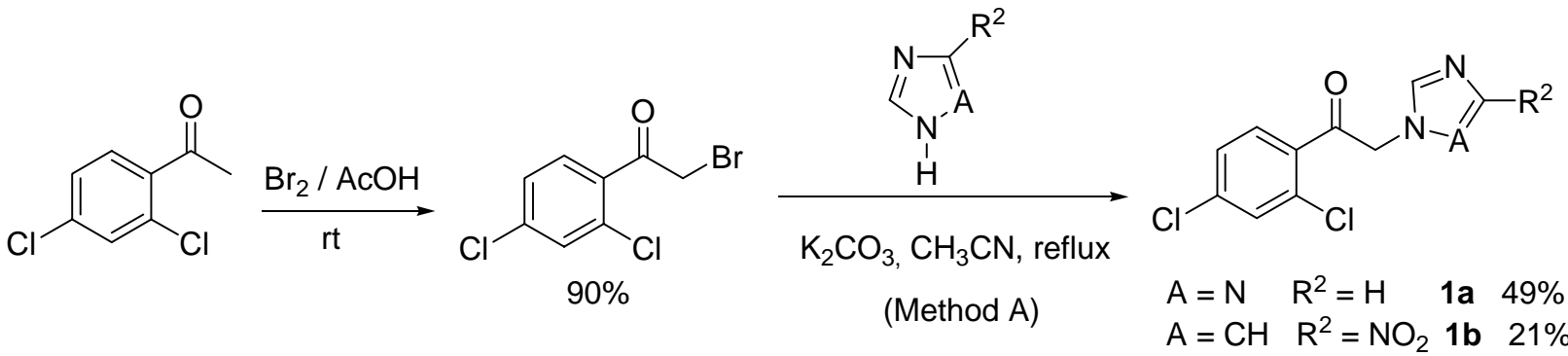<smiles>[R]CC(=O)C1=CC=[Y][Y]C=C1F</smiles>

1) $\mathrm{Br}_{2}, \mathrm{Et}_{2} \mathrm{O} /$ dioxane, rt

2) excess imidazole, $\mathrm{MeOH}, \mathrm{rt}$<smiles>[R]C(C(=O)c1c[Y]:[Y]cc1F)n1ccnc1</smiles>

(Method B)

$$
\begin{array}{llll}
\mathrm{Y}=4-\mathrm{F} & \mathrm{R}^{1}=\mathrm{H} & \mathbf{1 d} & 85 \% \\
\mathrm{Y}=\mathrm{H} & \mathrm{R}^{1}=\mathrm{CH}_{3} & \mathbf{1 e} & 93 \% \\
\mathrm{Y}=4-\mathrm{MeO} & \mathrm{R}^{1}=\mathrm{H} & \mathbf{1 f} & 72 \% \\
\mathrm{Y}=5-\mathrm{CF}_{3} & \mathrm{R}^{1}=\mathrm{H} & \mathbf{1 g} & 56 \%
\end{array}
$$<smiles>CC(=O)c1cc[Y]cc1F</smiles>

$\underset{\mathrm{rt}}{\stackrel{\mathrm{Br}_{2} / \mathrm{AcOH}}{\longrightarrow}}$<smiles>[Y][Y]1ccc(F)c(C(=O)C(C)Br)c1</smiles>

(Method C)

$$
\begin{array}{ll}
Y=H & 83 \% \\
Y=5-\mathrm{CF}_{3} & 82 \%
\end{array}
$$
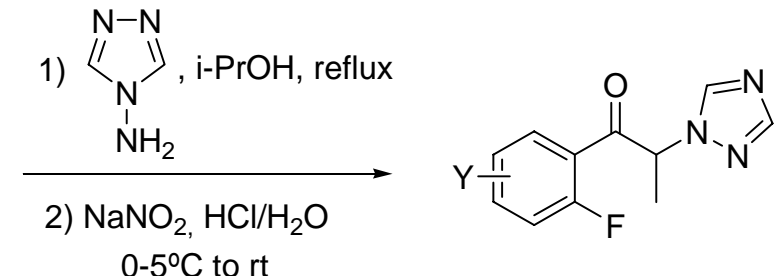

$\begin{array}{lll}Y=H & 1 \mathbf{i} & 93 \% \\ \mathrm{Y}=5-\mathrm{CF}_{3} & \mathbf{1 j} & 82 \%\end{array}$

\section{Scheme 3}

Oxiranes 2 were obtained by methylenation of ketones 1 . Two sets of conditions were used (Scheme 4). Epoxides 2a-c, 2f-g, 2i-j were prepared with trimethylsulfoxonium iodide as methylenating agent, ${ }^{7}$ sodium hydroxide as base, in water-dichloromethane in the presence of a phase-transfer catalyst. Oxiranes $\mathbf{2 d}, \mathbf{2 e}, \mathbf{2 h}$ were obtained by treatment of the corresponding ketones with dimethylsulfonium methylide, generated from methyl trimethylsulfonium sulfate and sodium hydroxide, in water-dichloromethane in the absence of a phase-transfer agent. ${ }^{8}$ In general, the isolated yields were good, but the reaction failed for ketone $\mathbf{1 b}$ and total conversion was not achieved with ketone 1g. Oxirane $\mathbf{2 g}$ decomposed upon attempted chromatographic purification. In all other cases the crude products were pure enough $\left({ }^{1} \mathrm{H} \mathrm{NMR}\right)$ to be used directly in the next step without further purification. Compounds $\mathbf{2 e}, \mathbf{2} \mathbf{h}-\mathbf{j}$ were obtained as diastereoisomeric mixtures, which were not separated. 

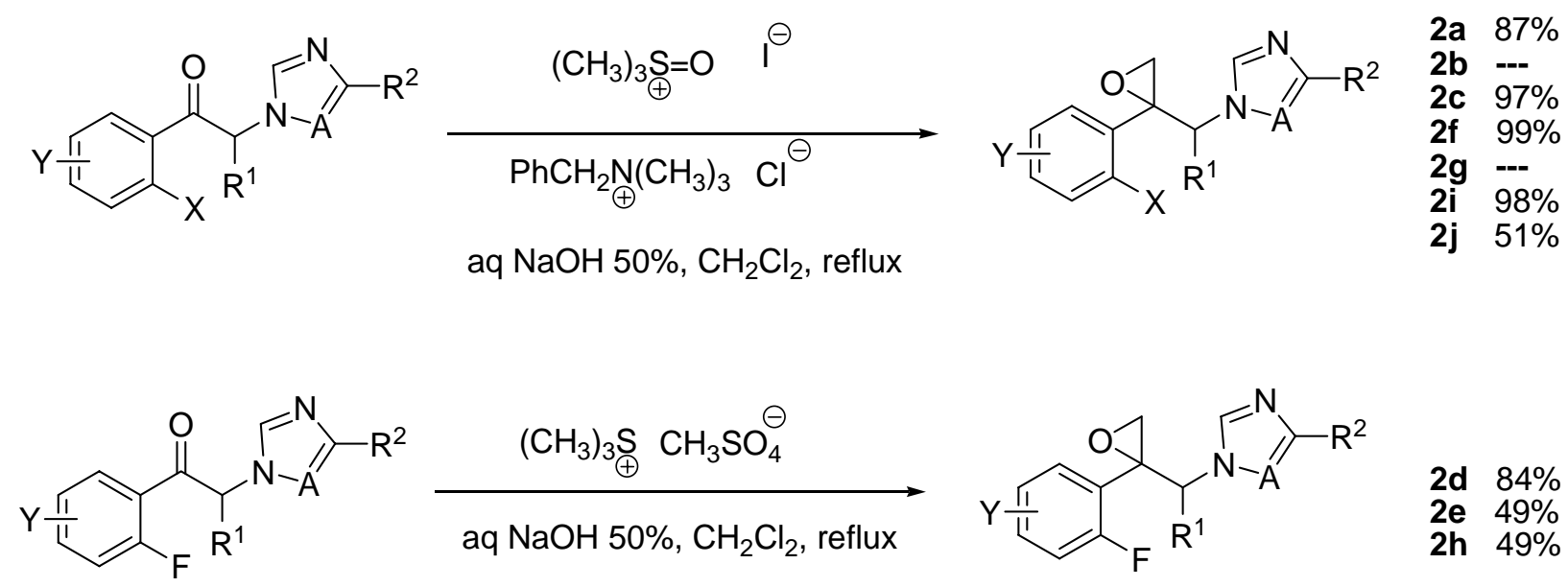

\section{Scheme 4}

Once the oxiranes 2 became available we undertook the preparation of benzo[b]furans 3 by treatment of $\mathbf{2}$ with sodium tert-butoxide in anhydrous dimethylsulfoxide (Scheme 5, Table 2).<smiles>Clc1ccc(C2(Cn3cncn3)CO2)c(Cl)c1</smiles>

$\mathbf{2 a}$

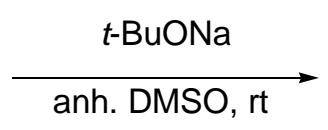

anh. DMSO<smiles>Clc1ccc2c(Cn3cncn3)coc2c1</smiles>

3a (18\%)<smiles>OC/C(=C\n1cncn1)c1ccc(Cl)cc1Cl</smiles>

$4(13 \%)$<smiles>[Y][Y]1ccc(F)c(C2(C([R])n3cncn3)CO2)c1</smiles>

2<smiles>[R1]C(c1coc2c1=CC=C[Y]([Y])([H])C=2)n1cncn1</smiles>

\section{Scheme 5}

When performing the reaction with 2a at room temperature, only an $18 \%$ isolated yield of the desired benzo[b]furan 3a was obtained, together with a $13 \%$ of a mixture of $(E, Z)$ isomers of the allylic alcohol 4 (Scheme 5). When the isolated 4 was treated with the same base in anhydrous DMSO at $60^{\circ} \mathrm{C}$, a mixture of $\mathbf{3 a}$ and $\mathbf{4}$ was again observed. Complete conversion to the cyclized compound 3a was not possible. It was clear from this result that the chloro group was not a good enough leaving group in the intramolecular $\mathrm{S}_{\mathrm{N}} \mathrm{Ar}$ process. Then, we turned to fluorinated oxiranes. Benzo[b]furan $\mathbf{3 c}$ and $\mathbf{3 j}$ were obtained from epoxides $\mathbf{2} \mathbf{c}$ and $\mathbf{2} \mathbf{j}$ at room temperature in fairly good yields after chromatographic purification. In the other cases, heating 
of the solution at $60^{\circ} \mathrm{C}$ for one or two days was required for complete conversion, and the isolated yields of $\mathbf{3}$ after chromatography were modest. For $\mathbf{3 d}$ and $\mathbf{3 i}$, although the presence of the desired compounds could be observed in the ${ }^{1} \mathrm{H}$ NMR spectra of the crude mixtures, the high complexity of these mixtures precluded the isolation of pure compounds. In an attempt to improve the results another base was tested. Thus, oxirane $\mathbf{2 c}$ was treated with lithium diisopropylamide in THF at room temperature. The ${ }^{1} \mathrm{H}$ NMR spectrum of the crude mixture showed the presence of compounds with a benzofuran moiety and an allylic alcohol moiety in a 1:6 ratio. Addition of a radical scavenger (galvinoxyl) to the reaction between $2 \mathrm{c}$ and sodium tert-butoxide did not affect the course of the process, excluding a pathway through radical intermediates.

Table 2. Conditions and yields for the preparation of 3

\begin{tabular}{ccc}
\hline 3 & Temperature / time & \% Isolated yield \\
\hline 3c & rt / $24 \mathrm{~h}$ & 64 \\
3d & $\mathrm{rt} / 24 \mathrm{~h}$, then $60^{\circ} \mathrm{C} / 20 \mathrm{~h}$ & complex mixture \\
3e & $\mathrm{rt} / 24 \mathrm{~h}$, then $60^{\circ} \mathrm{C} / 48 \mathrm{~h}$ & 16 \\
$\mathbf{3 f}$ & $\mathrm{rt} / 24 \mathrm{~h}$, then $60^{\circ} \mathrm{C} / 24 \mathrm{~h}$ & 17 \\
$\mathbf{3 h}$ & $\mathrm{rt} / 24 \mathrm{~h}$, then $60^{\circ} \mathrm{C} / 24 \mathrm{~h}$ & 18 \\
$\mathbf{3 i}$ & $\mathrm{rt} / 24 \mathrm{~h}$, then $60^{\circ} \mathrm{C} / 20 \mathrm{~h}$ & complex mixture \\
$\mathbf{3 j}$ & $\mathrm{rt} / 24 \mathrm{~h}$ & 54 \\
\hline
\end{tabular}

\section{Attempted preparation of substituted 3-methyl(or ethyl)benzo[b]furans}

The general synthetic pathway for the preparation of benzo[b]furan derivatives 7 which do not bear the azole moiety is outlined in Scheme 6. The corresponding epoxides 5 were prepared by standard methodologies, by direct methylenation of commercial ketones or by a two step strategy involving Wittig olefination of ketones to give compounds 6 and subsequent epoxidation with $m$-chloroperbenzoic acid. However, all attempts to promote the formation of heterocycles 7 from oxiranes $\mathbf{5}$ were unsuccessful. Several basic conditions were tested. When $\mathbf{5 k}$ and $\mathbf{5 l}$ were treated with one equivalent of lithium diisopropylamide (LDA) in THF at $-78^{\circ} \mathrm{C}$ and then at reflux temperature, complex mixtures were obtained (GC-MS, ${ }^{1} \mathrm{H}$ NMR) containing regioisomeric oxirane products resulting from the substitution of one halogen atom of the aromatic ring by the diisopropylamino group. This was an indication that the base had acted also as a nucleophile through a benzyne intermediate. Treatment of oxiranes $\mathbf{5 k}$ and $\mathbf{5 m}$ with sterically hindered and non nucleophilic bases such as potassium bis(trimethylsilyl)amide (KHMDS) produced also substitution of the halogen group. Treatment of $\mathbf{5 k}$ with sodium tert-butoxide in anhydrous DMSO at $60^{\circ} \mathrm{C}$ gave no reaction, the starting compound being recovered. Complex mixtures were obtained from $5 \mathbf{k}$ and $\mathbf{5 l}$ by using phosphazene or Schwesinger bases ${ }^{9}$ in $\mathrm{THF}$ at $-78^{\circ} \mathrm{C}$, no defined products being isolated. 


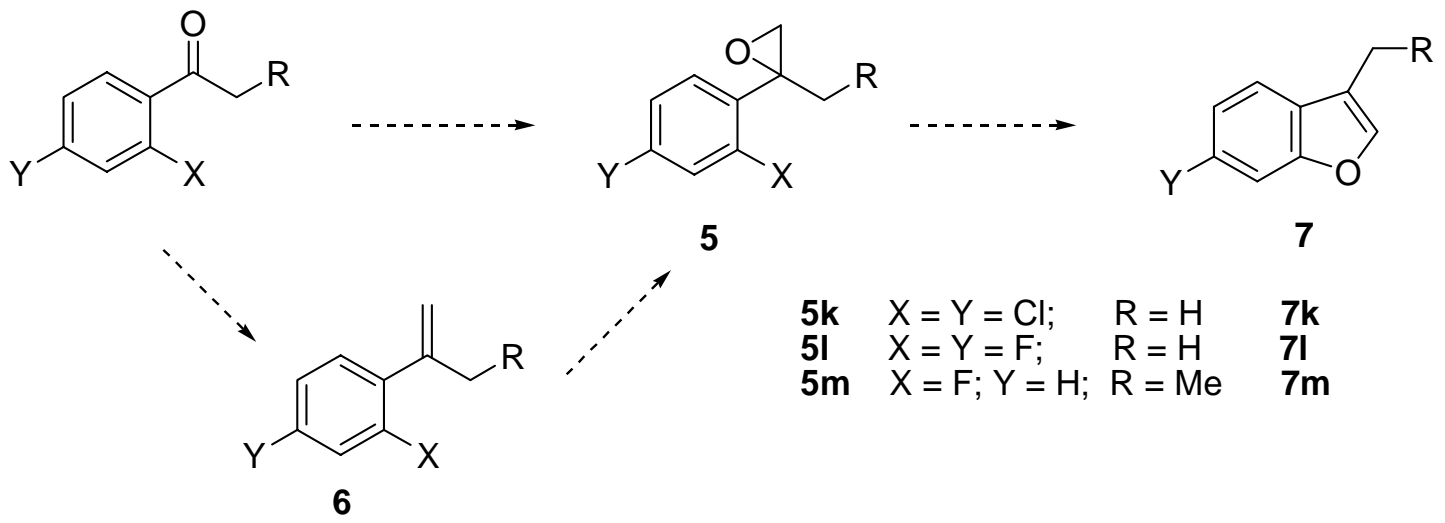

\section{Scheme 6}

\section{Conclusions}

The scope of the synthesis of benzo[b]furans by an approach involving opening of 2-(2'halogenoaryl)oxiranes with base and subsequent cyclization of the alkoxide intermediate by an intramolecular $\mathrm{S}_{\mathrm{N}} \mathrm{Ar}$ reaction has been studied. It seems clear from our results that an azole moiety (imidazole, triazole) is required for the formation of benzo[b]furan derivatives. The reason is that the negative charge in the intermediate carbanion is delocalized through the conjugated azole moiety (dipole stabilized side chain $\mathrm{N}-\mathrm{C} \alpha$ carbanions). As expected from an $\mathrm{S}_{\mathrm{N}} \mathrm{Ar}$ process, electron-withdrawing groups in the aromatic ring favour the intramolecular cyclization and this is also much more successful with 2'-fluoroaryl than with 2'-chloroaryl groups, in accordance with the leaving-group ability of fluoro and chloro groups in this type of reactions. This methodology involves the formation of O1-C7a bond of the heterocycle in the cyclization step.

\section{Experimental Section}

General Procedures. Melting points were measured with a Kofler Reicherdt apparatus and are uncorrected. GC analyses were performed in a Hewlett-Packard 5890 II Plus, with a column HP5 (cross-linked 5\%, Ph-Me silicone, $30 \mathrm{~m}$ x $0.32 \mathrm{~mm}$ x $0.25 \mu \mathrm{m}$ ). IR data were obtained on a Nicolet 510 ZDX FTIR spectrophotometer. ${ }^{1} \mathrm{H}$ NMR spectra $(250 \mathrm{MHz})$ and ${ }^{13} \mathrm{C}$ NMR $(62.5$ $\mathrm{MHz}$ ) were recorded on a Bruker AC-250. Chemical shifts $\left(\delta\right.$, ppm) were referenced to $\mathrm{Me}_{4} \mathrm{Si}$ $\left({ }^{1} \mathrm{H}\right.$ and $\left.{ }^{13} \mathrm{C}\right)$. The abbreviations used are s for singlet, $\mathrm{d}$ for doublet, dd for double doublet, $\mathrm{t}$ for triplet, q for quartet and $\mathrm{m}$ for multiplet. Mass spectra (MS-EI) were determined at the Servei d'Anàlisi de la Universitat Autònoma de Barcelona on a Hewlett-Packard 5989A spectrometer, using impact ionization at $70 \mathrm{eV}$. HRMS have been determined at the Servicio de Espectrometría 
de Masas de la Universidad de Córdoba. Elemental analyses have been performed at the Servei d'Anàlisi de la Universitat Autònoma de Barcelona. Ketone 1c was provided by Ferrer Internacional S. A.

1-(2',4'-Dichlorophenyl)-2-(1H-1,2,4-triazol-1-yl)ethanone (1a). A stirred mixture of triazole (4.50 g, $65.2 \mathrm{mmol})$ and potassium carbonate $(9.50 \mathrm{~g}, 68.7 \mathrm{mmol})$ in $\mathrm{CH}_{3} \mathrm{CN}$ (45 mL) was heated at $90^{\circ} \mathrm{C}$ for $2 \mathrm{~h}$. A solution of 2-chloro-1-(2',4'-dichlorophenyl)ethanone (15.09 g, $\left.67.5 \mathrm{mmol}\right)$ in $\mathrm{CH}_{3} \mathrm{CN}$ (45 mL) was added. The reaction mixture became red and was stirred at RT overnight. The solid was filtered off, the solvent from the filtrate was evaporated under reduced pressure and the residue was partitioned between water and ethyl acetate. The organic phase was dried over anhydrous sodium sulfate and evaporated. The resulting oil was treated with hot diethyl ether and dichloromethane to afford 1a as a yellow solid (2.90 g). The residue from the digestion was chromatographed on silica gel (ethyl acetate-dichloromethane 3:7) to give 1a (3.7 g). The combined yield was $40 \%$ (6.6 g); mp $112-116^{\circ} \mathrm{C}$ (lit ${ }^{10} \mathrm{mp} 115-116^{\circ} \mathrm{C}$ ); IR (KBr, cm${ }^{-1}$ ) 2992, 1712, 1584, 1273, 1224, 1013, 813; ${ }^{1} \mathrm{H}$ NMR $\left(\mathrm{CDCl}_{3}\right) \delta 5.64$ (s, 2H), 7.41 (d, J = $\left.8.1 \mathrm{~Hz}, 1 \mathrm{H}\right)$, $7.53(\mathrm{~s}, 1 \mathrm{H}), 7.68$ (d, J = $8.1 \mathrm{~Hz}, 1 \mathrm{H}), 8.01(\mathrm{~s}, 1 \mathrm{H}), 8.23(\mathrm{~s}, 1 \mathrm{H}) ;{ }^{13} \mathrm{C} \mathrm{NMR}\left(\mathrm{CDCl}_{3}\right) \delta 57.8$, 127.9, 130.8, 131.5, 133.7, 136.0, 139.5, 144.7, 152.2, 192.1.

2-Bromo-1-(2',4'-dichlorophenyl)ethanone. Bromine (9.33 g, $58.4 \mathrm{mmol}$ ) was added dropwise to a solution of 1-(2',4'-dichlorophenyl)ethanone (10.00 g, $52.9 \mathrm{mmol})$ in glacial acetic acid (23 $\mathrm{mL}$ ). The mixture was stirred at RT for $2 \mathrm{~h}$. Then water was added and extractions with chloroform were made. The organic phase was washed with water until neutral $\mathrm{pH}$, it was dried over anhydrous sodium sulfate and the solvent was evaporated under reduced pressure to give the desired compound ${ }^{11}$ as an oil (12.68 g, ca 90\%). The ${ }^{1} \mathrm{H}$ NMR spectrum showed the presence of minor quantities of the dibrominated compound and the starting ketone; IR (film, $\mathrm{cm}^{-1}$ ) 1697, 1584, 1374, 1277, 1240, 1104, 819, 574; ${ }^{1} \mathrm{H}$ NMR $\left(\mathrm{CDCl}_{3}\right) \delta 4.49$ (s, 2H), 7.33-7.57 (m, $3 \mathrm{H}) ;{ }^{13} \mathrm{C}$ NMR $\left(\mathrm{CDCl}_{3}\right) \delta 34.1,127.3,130.5,131.1,132.2,133.9,138.5,192.2$.

1-(2',4'-Dichlorophenyl)-2-(4-nitro-1H-1-imidazolyl)ethanone (1b). A stirred mixture of 4(5)nitro- $1 \mathrm{H}$-imidazole (3.85 g, $34.2 \mathrm{mmol})$ and potassium carbonate $(4.98 \mathrm{~g}, 50.8 \mathrm{mmol})$ in $\mathrm{CH}_{3} \mathrm{CN}$ (40 mL) was heated at $90^{\circ} \mathrm{C}$ for $2 \mathrm{~h}$. A solution of 2-bromo-1-(2',4'-dichlorophenyl)ethanone (10.04 g, $37.4 \mathrm{mmol}$ ) in $\mathrm{CH}_{3} \mathrm{CN}(15 \mathrm{~mL})$ was added. The reaction mixture was stirred at RT for $15 \mathrm{~h}$. The solid was filtered off, the solvent from the filtrate was evaporated under reduced pressure and the residue was partitioned between water and ethyl acetate. A brown solid precipitated in the interphase and it was filtered. Addition of diethyl ether to the organic phase caused the precipitation of a second batch of solid. The combined yield was 20\% (1.97 g); mp $158-161^{\circ} \mathrm{C}$ (ethyl acetate); IR (KBr, $\mathrm{cm}^{-1}$ ) 1718, 1580, 1547, 1489, 1375, 1339, 1291, 1217, 983, 821; ${ }^{1} \mathrm{H}$ NMR $\left(\mathrm{CD}_{3} \mathrm{COCD}_{3}\right) \delta 5.76(\mathrm{~s}, 2 \mathrm{H}), 7.65$ (dd, J = 8.0, $\left.2.2 \mathrm{~Hz}, 1 \mathrm{H}\right), 7.79(\mathrm{~d}, \mathrm{~J}=2.2 \mathrm{~Hz}$, $1 \mathrm{H}), 7.82$ (s, $1 \mathrm{H}), 7.99$ (d, J = 8.0 Hz, 1H); ${ }^{13} \mathrm{C} \mathrm{NMR}\left(\mathrm{CD}_{3} \mathrm{COCD}_{3}\right) \delta$ 56.1, 123.0, 128.0, 130.9, 132.2, 132.7, 133.1, 138.1, 138.9, 147.1, 192.7; MS m/z : 264 ( $\left.\mathrm{M}^{+}-\mathrm{Cl}, 1\right), 177$ (10), 175 (65), 173 (100), 145 (18); $\mathrm{C}_{10} \mathrm{H}_{7} \mathrm{Cl}_{2} \mathrm{~N}_{3} \mathrm{O}_{3} . \mathrm{H}_{2} \mathrm{O}$ : calcd. C 41.53, $\mathrm{H} \mathrm{2.85,} \mathrm{N} \mathrm{13.21;} \mathrm{found} \mathrm{C} \mathrm{41.62,} \mathrm{H}$ 2.42, N 14.23. 
1-(2',4'-Difluororophenyl)-2-(1H-1-imidazolyl)ethanone (1d). In a flask fitted with an acid trap and placed in an ice-water bath, bromine (2 mL, $6.22 \mathrm{~g}, 38.9 \mathrm{mmol})$ was slowly added to a stirred solution of 1-(2',4'-difluorophenyl)ethanone (4.01 g, $25 \mathrm{mmol})$ in dioxane (12 mL) and diethyl ether (25 mL). Then a solution of imidazole $(8.56 \mathrm{~g}, 121.0 \mathrm{mmol})$ in methanol $(15 \mathrm{~mL})$ was added, maintaining the temperature between 5 and $10^{\circ} \mathrm{C}$. The mixture was stirred at RT for $24 \mathrm{~h}$. It was poured into $50 \mathrm{~mL}$ of water and extracted with dichloromethane. The organic phase was extracted with $1 \mathrm{M} \mathrm{HCl}(4 \times 10 \mathrm{~mL})$. The aqueous phase was neutralized with an aqueous solution of sodium carbonate and extracted with dichloromethane. The organic phase was dried over anhydrous sodium sulfate and the solvent was evaporated to give 1d (4.84 g, 85\%); mp 123$125^{\circ} \mathrm{C}$ (diethyl ether) (lit $\left.{ }^{12} \mathrm{mp} 125-127^{\circ} \mathrm{C}\right)$; IR $\left(\mathrm{KBr}, \mathrm{cm}^{-1}\right) 3100,2952,1703,1611,1426,1241$, 1103; ${ }^{1} \mathrm{H}$ NMR $\left(\mathrm{CDCl}_{3}\right) \delta 5.25$ (broad s, 2H), 6.89 (s, 1H), 6.92-7.04 (m, 2H), 7.09 (s, 1H), 7.45 (s, 1H), 8.00 (dd, J = 8.7, $6.5 \mathrm{~Hz}, 1 \mathrm{H}) ;{ }^{13} \mathrm{C} \mathrm{NMR}\left(\mathrm{CDCl}_{3}\right) \delta$ 56.9, 104.8, 112.9, 120.1, 129.3, 133.0, 137.9, 160.9, 164.7, 168.6, 188.7 ; MS m/z : 222 (M+, 19), 141 (100), 113 (17).

1-(2-Fluororophenyl)-2-(1H-1-imidazolyl)-1-propanone (1e). In a flask fitted with an acid trap and placed in an ice-water bath, bromine $(1.5 \mathrm{~mL}, 4.66 \mathrm{~g}, 29.2 \mathrm{mmol})$ was slowly added to a stirred solution of 1-(2-fluorophenyl)-1-propanone (3.00 g, $19.7 \mathrm{mmol})$ in dioxane (4 mL) and diethyl ether $(8 \mathrm{~mL})$. Then a solution of imidazole $(6.94 \mathrm{~g}, 102 \mathrm{mmol})$ in methanol $(10 \mathrm{~mL})$ was added, maintaining the temperature between 5 and $10^{\circ} \mathrm{C}$. The mixture was stirred at RT for $24 \mathrm{~h}$. It was poured into $25 \mathrm{~mL}$ of water and extracted with dichloromethane. The organic phase was washed with an aqueous solution of sodium hydrogenosulfite and then extracted with $1 \mathrm{M} \mathrm{HCl}$ $(4 \times 10 \mathrm{~mL})$. The aqueous phase was neutralized with an aqueous solution of sodium carbonate and extracted with dichloromethane. The organic phase was dried over anhydrous sodium sulfate and the solvent was evaporated to give 1e as a red oil (3.90 g, 93\%); IR (film, $\mathrm{cm}^{-1}$ ) 3119, 2995, 1695, 1510, 1483, 1453, 1208; ${ }^{1} \mathrm{H}$ NMR $\left(\mathrm{CDCl}_{3}\right) \delta 1.7$ (d, J = 7.3 Hz, 3H), 5.67 (q, J = 7.3 Hz, 1H), 6.90 (s, 1H), 7.01 (s, 1H), 7.12-7.25 (m, 2H), 7.52 (m, 1H), 7.56 (s, 1H), 7.78 (apparent t, J $=9.5 \mathrm{~Hz}, 1 \mathrm{H}) ;{ }^{13} \mathrm{C} \mathrm{NMR}\left(\mathrm{CDCl}_{3}\right) \delta 18.1,60.1,116.7,118.1,123.0,125.2,129.2,131.3,135.5$, 136.4, 163.1, 194.3 ; MS m/z : 218 (M+, 45), 123 (100), 95 (59); HRMS Calcd. $\mathrm{C}_{12} \mathrm{H}_{11} \mathrm{FN}_{2} \mathrm{O}$ : 218.0855, Found: 218.0863.

1-(2'-Fluoro-4'-methoxyphenyl)-2-(1H-1-imidazolyl)ethanone (1f). In a flask fitted with an acid trap and placed in an ice-water bath, bromine (2 mL, $6.22 \mathrm{~g}, 39 \mathrm{mmol}$ ) was slowly added to a stirred solution of 1-(2'-fluoro-4'-methoxyphenyl)ethanone (5.00 g, $29.7 \mathrm{mmol}$ ) in dioxane (6 $\mathrm{mL}$ ) and diethyl ether (12 mL). Then a solution of imidazole (10.12 g, $140 \mathrm{mmol})$ in methanol (8 $\mathrm{mL}$ ) was added, maintaining the temperature between 5 and $10^{\circ} \mathrm{C}$. The mixture was stirred at RT for $12 \mathrm{~h}$. It was poured into $50 \mathrm{~mL}$ of water and extracted with dichloromethane. The organic phase was dried over anhydrous sodium sulfate and the solvent was evaporated to give a red oil, which was dissolved in dichloromethane. Addition of diethyl ether resulted in the precipitation of 1f as a solid (5.04 g, 72\%); IR (film, $\mathrm{cm}^{-1}$ ) 3114, 2945, 1689, 1616, 1572, 1504, 1442, 1293, 1245, 1159, 1119, 1104; ${ }^{1} \mathrm{H}$ NMR $\left(\mathrm{CDCl}_{3}\right) \delta 3.90$ (s, 3H), 5.28 (d, J = 3.6 Hz, 2H), 6.60 (dd, J = 13.1, $2.2 \mathrm{~Hz}, 1 \mathrm{H}$ ), 6.83 (dd, J = 9.5, $2.2 \mathrm{~Hz}, 1 \mathrm{H}$ ), 6.94 (s, 1H), 7.12 (s, 1H), 7.51 (s, 1H), 7.96 (apparent t, J = $8.8 \mathrm{~Hz}, 1 \mathrm{H})$; MS m/z : $234\left(\mathrm{M}^{+}, 10\right), 153$ (100), 110 (8). It was dissolved in 
ethanol and a saturated solution of picric acid was added. The corresponding picrate was obtained as a yellow solid; mp $165-167^{\circ} \mathrm{C}$ (methanol); IR $\left(\mathrm{KBr}, \mathrm{cm}^{-1}\right) 1615,1567,1365,1339$, 1327, 1294, 1269, 1242; ${ }^{1} \mathrm{H}$ NMR $\left(\mathrm{CD}_{3} \mathrm{COCD}_{3}\right) \delta 3.88(\mathrm{~s}, 3 \mathrm{H}), 5.78$ (d, J = 3.6 Hz, 2H), 6.967.11 (m, 2H), 7.63 (broad s, 1H), 7.70 (broad d, 1H), 7.91 (apparent t, J = 8.8 Hz, 1H), 8.57 (s, $2 \mathrm{H}), 8.99$ (s, $1 \mathrm{H}) ; \mathrm{C}_{18} \mathrm{H}_{14} \mathrm{FN}_{5} \mathrm{O}_{9.1} 1 / 2 \mathrm{H}_{2} \mathrm{O}$ : calcd. C 45.77, $\mathrm{H} \mathrm{3.20,} \mathrm{N} \mathrm{14.83;} \mathrm{found} \mathrm{C} \mathrm{45.72,} \mathrm{H}$ 3.03, N 14.26.

1-(2'-Fluoro-5'-trifluoromethylphenyl)-2-(1H-1-imidazolyl)ethanone (1g). In a flask fitted with an acid trap and placed in an ice-water bath, bromine $(1.6 \mathrm{~mL}, 4.97 \mathrm{~g}, 31.1 \mathrm{mmol})$ was slowly added to a stirred solution of 1-(2'-fluoro-5'-trifluoromethylphenyl)ethanone (5.00 g, $23.8 \mathrm{mmol})$ in dioxane $(5 \mathrm{~mL})$ and diethyl ether $(10 \mathrm{~mL})$. Then a solution of imidazole $(8.12 \mathrm{~g}$, $110 \mathrm{mmol})$ in methanol $(9 \mathrm{~mL})$ was added, maintaining the temperature between 5 and $10^{\circ} \mathrm{C}$. The mixture was stirred at RT for $24 \mathrm{~h}$. It was poured into $25 \mathrm{~mL}$ of water and extracted with ethyl acetate. The organic phase was washed with an aqueous solution of sodium hydrogenosulfite and then with water, it was dried over anhydrous sodium sulfate and the solvent was evaporated to give $1 \mathrm{~g}$ as a red oil (3.69 g, 56\%); IR (film, $\mathrm{cm}^{-1}$ ) 3104, 2958, 1707, 1620, 1505, 1330, 1268, 1233, 1188, 1170, 1124, 1076, 636, 613; ${ }^{1} \mathrm{H}$ NMR $\left(\mathrm{CDCl}_{3}\right) \delta 5.31$ (d, J = $\left.2.9 \mathrm{~Hz}, 2 \mathrm{H}\right), 6.87$ (s, 1H), 7.05 (s, 1H), 7.34 (apparent t, $\mathrm{J}=10 \mathrm{~Hz}, 1 \mathrm{H}), 7.44$ (s, 1H), 7.81-7.87 (m, 1H), 8.20 (dd, $\mathrm{J}=$ 5.8, $2.2 \mathrm{~Hz}, 1 \mathrm{H}) ;{ }^{13} \mathrm{C} \mathrm{NMR}\left(\mathrm{CDCl}_{3}\right) \delta$ 56.1, 116.4, 117.7, 118.1, 120.2, 120.8, 122.8, 123.1, 125.1, 127.8, 128.8, 129.4, 132.9, 138.1, 165.7 (d, J = 259.1 Hz), 189.2 (d, J = 5.5 Hz); MS m/z : $272\left(\mathrm{M}^{+}, 35\right), 191$ (100), 163 (23), 81 (36).

1-(2',4'-Difluorophenyl)-2-(1H-1,2,4-triazol-1-yl)-1-propanone (1h). A suspension of $\mathrm{NaH}$ (0.99 g, $24.6 \mathrm{mmol})$ in anhydrous THF $(10 \mathrm{~mL})$ was slowly added under nitrogen atmosphere to a stirred solution of 1c $(4.00 \mathrm{~g}, 17.9 \mathrm{mmol})$ in anhydrous THF $(10 \mathrm{~mL})$. The stirred mixture was left $2 \mathrm{~h}$ at RT and heated $2 \mathrm{~h}$ under reflux. It was cooled to RT, methyl iodide was added (1.4 $\mathrm{mL}, 3.19 \mathrm{~g}, 22.5 \mathrm{mmol}$ ) and the stirred mixture was left at RT for $12 \mathrm{~h}$ (GC monitoring). It was poured into $30 \mathrm{~mL}$ of water and extracted with dichloromethane. The organic phase was dried with anhydrous sodium sulfate and the solvent was evaporated to give a mixture 8:1 ( ${ }^{1} \mathrm{H} \mathrm{NMR}$ ) of mono and dialkylated compounds, which were separated by column chromatography through silica gel (chloroform:ethyl acetate 4:1). Compound $\mathbf{1 h}^{13}$ eluted as a yellow oil (1.11 g, 26\%); IR (film, $\mathrm{cm}^{-1}$ ) 3103, 1699, 1612, 1530, 1423, 1274, 1240, 1202, 1143, 1095, 977; ${ }^{1} \mathrm{H}$ NMR $\left(\mathrm{CDCl}_{3}\right) \delta 1.74(\mathrm{~d}, \mathrm{~J}=7.3 \mathrm{~Hz}, 3 \mathrm{H}), 5.88$ (q, J = 7.3 Hz, 1H), 6.78-6.97 (m, 2H), 7.82-7.92 (m, 2H), $8.23(\mathrm{~s}, 1 \mathrm{H}) ;{ }^{13} \mathrm{C} \mathrm{NMR}\left(\mathrm{CDCl}_{3}\right) \delta 17.2,63.1,104.9,112.9,113.3,133.6,143.2,151.7$, 164.3, 168.7, 191.6; MS m/z : 237 (M+2), 222 (3), 141 (100), 113 (13).

2-Bromo-1-(2'-fluorophenyl)-1-propanone. In a flask fitted with an acid trap and placed in an ice-water bath, bromine $(2.2 \mathrm{~mL}, 6.84 \mathrm{~g}, 42.8 \mathrm{mmol})$ was slowly added to a stirred solution of 1(2'-fluorophenyl)-1-propanone (5.00 g, $32.9 \mathrm{mmol})$ in glacial acetic acid (30 mL). The mixture was left at RT under stirring for $3 \mathrm{~h}$. It was poured into $50 \mathrm{~mL}$ of water and extracted with chloroform. The organic phase was washed with water until neutral $\mathrm{pH}$, it was dried with anhydrous sodium sulfate and the solvent was evaporated to afford the desired compound as a yellow oil ${ }^{14}$ (7.06 g, 93\%); IR (film, $\mathrm{cm}^{-1}$ ) 1687, 1610, 1452, 1275, 753; ${ }^{1} \mathrm{H}$ NMR $\left(\mathrm{CDCl}_{3}\right)$ 
$\delta 1.80(\mathrm{~d}, \mathrm{~J}=6.6 \mathrm{~Hz}, 3 \mathrm{H}), 5.23$ (q, J = 6.6 Hz, 1H), 7.02-7.24 (m, 2H), 7.46 (m, 1H), 7.82 (apparent td, J = 7.3, $2.0 \mathrm{~Hz}, 1 \mathrm{H}) ;{ }^{13} \mathrm{C} \mathrm{NMR}\left(\mathrm{CDCl}_{3}\right) \delta 19.8,46.6(\mathrm{~d}, \mathrm{~J}=9.1 \mathrm{~Hz}), 116.1(\mathrm{~d}, \mathrm{~J}=$ $9.2 \mathrm{~Hz}$ ), 116.5 (d, J = 11.0 Hz), 124.5 (d, J = 3.7 Hz), 131.3, 134.8 (d, J = 9.2 Hz), 160.8 (d, J = $253.6 \mathrm{~Hz}$ ), 191.9 (d, J = 3.7 Hz); MS m/z : 232 (3), 230 ( $\left.\mathrm{M}^{+}, 3\right), 123$ (100), 95 (19).

1-(2'-Fluorophenyl)-2-(1H-1,2,4-triazol-1-yl)-1-propanone (1i). A solution of 2-bromo-1-(2'fluorophenyl)-1-propanone (6.00 g, $30.3 \mathrm{mmol})$ and 4-amino-4H-1,2,4-triazole (2.54 g, 30.3 $\mathrm{mmol}$ ) in isopropanol (30 mL) was heated under reflux for $4 \mathrm{~h}$, and then isopropanol was distilled $\left(82^{\circ} \mathrm{C}, 760 \mathrm{~mm} \mathrm{Hg}\right)$. Water $(10 \mathrm{~mL})$, concentrated hydrochloric acid $(6 \mathrm{~mL})$ and a solution of sodium nitrite $(2.71 \mathrm{~g}, 39.2 \mathrm{mmol})$ in water $(10 \mathrm{~mL})$ were successively added to the residue, maintaining the temperature between $0-5^{\circ} \mathrm{C}$ with an ice-water bath. The solution was stirred at RT for $1 \mathrm{~h}$, then it was neutralized with potassium carbonate and the solid formed was filtered to afford $1 \mathbf{i}$ (3.17 g, 48\%); mp 56-58 ${ }^{\circ} \mathrm{C}$ (diethyl ether); IR (film, cm ${ }^{-1}$ ) 3138, 1691, 1609, 1509, 1480, 1452, 1284, 1209, 1150, 1097, 970; ${ }^{1} \mathrm{H}$ NMR $\left(\mathrm{CDCl}_{3}\right) \delta 1.81$ (d, J = $\left.7.3 \mathrm{~Hz}, 3 \mathrm{H}\right)$, 5.97 (q, J = 7.3 Hz, 1H), 7.09-7.28 (m, 2H), 7.51-7.60 (m, 1H), 7.85 (apparent td, J = 7.5, 2.2 Hz, $1 \mathrm{H}), 7.90$ (s, $1 \mathrm{H}), 8.28$ (s, $1 \mathrm{H}) ; \mathrm{C}_{11} \mathrm{H}_{10} \mathrm{FN}_{3} \mathrm{O}$ : calcd. C 60.27, H 4.60, N 19.17; found C 60.37, H 4.56, N 19.04.

2-Bromo-1-(2'-fluoro-5'-trifluoromethylphenyl)-1-propanone. In a flask fitted with an acid trap and placed in an ice-water bath, bromine (1.3 mL, $3.92 \mathrm{~g}, 24.5 \mathrm{mmol})$ was slowly added to a stirred solution of 1-(2'-fluoro-5'-trifluoromethylphenyl)-1-propanone (5.00 g, $20.4 \mathrm{mmol}$ ) in glacial acetic acid $(10 \mathrm{~mL})$. The mixture was left at RT under stirring for $3 \mathrm{~h}$. It was poured into $25 \mathrm{~mL}$ of water and extracted with chloroform. The organic phase was washed with water until neutral $\mathrm{pH}$, it was dried with anhydrous sodium sulfate and the solvent was evaporated to afford a yellow oil (5.57 g, 82\%); IR (film, $\mathrm{cm}^{-1}$ ) 1696, 1619, 1326, 1269, 1207, 1170, 1132, 1074, 836; ${ }^{1} \mathrm{H}$ NMR $\left(\mathrm{CDCl}_{3}\right) \delta 1.86(\mathrm{~d}, \mathrm{~J}=6.5 \mathrm{~Hz}, 3 \mathrm{H}), 5.23(\mathrm{q}, \mathrm{J}=6.5 \mathrm{~Hz}, 1 \mathrm{H}), 7.24$ (dd, J = 10.2, 8.6 Hz, 1H), 7.77 (m, 1H), 8.22 (dd, J = 5.8, $2.2 \mathrm{~Hz}, 1 \mathrm{H}) ;{ }^{13} \mathrm{C} \mathrm{NMR}\left(\mathrm{CDCl}_{3}\right) \delta 19.7,46.4$ (d, J = 9.1 Hz), 117.2, 117.5, 129.1 (t, J = 3.7 Hz), 131.6, 162.2 (d, J = 257.3 Hz), 190.6 (d, J = 3.7 Hz); MS m/z : 299 (1), $297\left(\mathrm{M}^{+}, 1\right), 191$ (100), 162 (17).

1-(2'-Fluoro-5'-trifluoromethylphenyl)-2-(1H-1,2,4-triazol-1-yl)-1-propanone (1j). A solution of 2-bromo-1-(2'-fluoro-5'-trifluoromethylphenyl)-1-propanone (5.08 g, $16.7 \mathrm{mmol}$ ) and 4-amino-4H-1,2,4-triazole (1.45 g, $19.0 \mathrm{mmol})$ in isopropanol (20 mL) was heated under reflux for $4 \mathrm{~h}$, and then isopropanol was distilled $\left(82^{\circ} \mathrm{C}, 760 \mathrm{~mm} \mathrm{Hg}\right)$. Water $(10 \mathrm{~mL})$, concentrated hydrochloric acid $(6 \mathrm{~mL})$ and a solution of sodium nitrite $(5.06 \mathrm{~g}, 73.3 \mathrm{mmol})$ in water $(6 \mathrm{~mL})$ were successively added to the residue, maintaining the temperature between $0-5^{\circ} \mathrm{C}$ with an ice-water bath. The solution was stirred at RT for $1 \mathrm{~h}$, then it was neutralized with potassium carbonate and it was extracted with dichloromethane. The organic phase was dried with anhydrous sodium sulfate and the solvent was evaporated to afford $\mathbf{1 j}$ as a red oil (3.97 g, 82\%); IR (film, $\mathrm{cm}^{-1}$ ) 1705, 1620, 1504, 1333, 1272, 1227, 1195, 1172, 1129, 1074, 811; ${ }^{1} \mathrm{H}$ NMR $\left(\mathrm{CDCl}_{3}\right) \delta 1.78(\mathrm{~d}, \mathrm{~J}=7.0 \mathrm{~Hz}, 3 \mathrm{H}), 5.92$ (q, J = 7.0 Hz, 1H), 7.23 (dd, J = 9.5, 8.0 Hz, 1H), 7.73-7.89 (m, 1H), 7.99 (s, 1H), 8.09 (dd, J = 5.8, 2.2 Hz, 1H), 8.25 (s, 1H); MS m/z : $287\left(\mathrm{M}^{+}\right.$, 1), 191 (100), 163 (20), 96 (13). Hydrogen chloride was bubbled into a solution of $\mathbf{1 j}$ in diethyl 
ether, 1j.HCl being obtained as a white solid; mp $111-112^{\circ} \mathrm{C}$ (ethyl acetate); $\mathrm{C}_{12} \mathrm{H}_{9} \mathrm{~F}_{4} \mathrm{~N}_{3} \mathrm{O}$. HCl . $1 / 2 \mathrm{H}_{2} \mathrm{O}$ : calcd. C 43.32, H 3.33, N 12.63; found C 42.84, H 3.10, N 12.93.

2-(2',4'-Dichlorophenyl)-2-(1H-1,2,4-triazol-1-ylmethyl)oxirane (2a). A $50 \%$ aqueous solution of $\mathrm{NaOH}(0.6 \mathrm{~mL}, 0.7 \mathrm{mmol})$ was slowly added to a stirred solution of $\mathbf{1 a}(1.99 \mathrm{~g}, 7.7$ mmol), trimethylsulfoxonium iodide $(1.81 \mathrm{~g}, 8.1 \mathrm{mmol})$, and benzyltrimethylammonium chloride (0.05 g, $0.2 \mathrm{mmol})$ in dichloromethane $(7.5 \mathrm{~mL})$. The mixture was heated under reflux for $24 \mathrm{~h}$. Water was added $(30 \mathrm{~mL})$ and it was extracted with dichloromethane. The organic phase was dried with anhydrous sodium sulfate and the solvent was evaporated affording a 87:12 mixture of $2 \mathbf{a}^{15}$ and $1 \mathbf{a}\left({ }^{1} \mathrm{H}\right.$ NMR molar ratio) as a red oil (1.43 g). It was taken in ethyl acetate $(5 \mathrm{~mL})$ and a solution of methanesulfonic acid $(0.4 \mathrm{~mL})$ in ethyl acetate $(7 \mathrm{~mL})$ was added. The mixture was stirred for one hour in an ice-water bath. The white solid formed was filtered and washed successively with ethyl acetate and diethyl ether, affording the methanesulfonate of $2 \mathbf{a}(0.69 \mathrm{~g}$, 34\%); mp 160-162 ${ }^{\circ} \mathrm{C}$; IR ( $\mathrm{KBr}, \mathrm{cm}^{-1}$ ) 3137, 3085, 3008, 1996, 1556, 1377, 1240, 1163, 1035 , 1004, 774, 555; ${ }^{1} \mathrm{H}$ NMR $\left(\mathrm{CD}_{3} \mathrm{COCD}_{3}\right) \delta 2.49$ (s, 3H), 2.94 (d, J = $\left.4.4 \mathrm{~Hz}, 1 \mathrm{H}\right), 3.16$ (d, J = 4.4 Hz, 1H), 4.62 (d, J = 15.4 Hz, 1H), 4.94 (d, J = 15.4 Hz, 1H), 7.15 (d, J = 8.1 Hz, 1H), 7.34 (dd, J = 8.1, $2.2 \mathrm{~Hz}, 1 \mathrm{H}), 7.65(\mathrm{~d}, \mathrm{~J}=2.2 \mathrm{~Hz}, 1 \mathrm{H}), 8.23(\mathrm{~s}, 1 \mathrm{H}), 8.86(\mathrm{~s}, 1 \mathrm{H}) ;) ;{ }^{13} \mathrm{C} \mathrm{NMR}\left(\mathrm{CD}_{3} \mathrm{COCD}_{3}\right)$ $\delta$ 51.8, 52.9, 58.1, 127.3, 128.6, 130.9, 133.1, 134.0, 144.4, 149.2

2-(2',4'-Difluorophenyl)-2-(1H-1,2,4-triazol-1-ylmethyl)oxirane (2c). A $50 \%$ aqueous solution of $\mathrm{NaOH}(15 \mathrm{~mL}, 187.5 \mathrm{mmol})$ was slowly added to a stirred solution of $1 \mathrm{c}$ (3.01 g, $13.5 \mathrm{mmol}$ ), trimethylsulfoxonium iodide (3.619 g, $15.9 \mathrm{mmol}$ ), and benzyltrimethylammonium chloride $(0.134 \mathrm{~g}, 0.7 \mathrm{mmol})$ in dichloromethane $(20 \mathrm{~mL})$. The mixture was heated under reflux for $24 \mathrm{~h}$. Water was added (50 mL) and it was extracted with dichloromethane. The organic phase was dried with anhydrous sodium sulfate and the solvent was evaporated affording 2c (3.12 g, 97\%) as a yellow-greenish oil; IR (film, $\mathrm{cm}^{-1}$ ) 3114, 3071, 3015, 1620, 1601, 1508, 1427, 1274, 1140, 1106, 1023, 965; ${ }^{1} \mathrm{H}$ NMR $\left(\mathrm{CDCl}_{3}\right) \delta 2.83$ (d, J = 5.0 Hz, 1H), 2.90 (d, J = 5.0 Hz, 1H), 4.46 (d, J = 14.6 Hz, 1H), 4.78 (d, J = 14.6 Hz, 1H), 6.80 (m, 2H), 7.13 (m, 1H), 7.82 (s, $1 \mathrm{H}), 8.02$ (s, $1 \mathrm{H})$; ). It was characterized as their methanesulfonate; mp $125-128^{\circ} \mathrm{C}$ (lit ${ }^{16} \mathrm{mp}$ 128-129 ${ }^{\circ}$ ); IR (KBr, cm ${ }^{-1}$ ) 3140, 3011, 2962-2345 (broad), 1990-1963 (broad), 1621, 1559, 1508, 1242, 1161, 1034, 967; ${ }^{1} \mathrm{H}$ NMR $\left(\mathrm{CD}_{3} \mathrm{SOCD}_{3}\right) \delta 2.41(\mathrm{~s}, 3 \mathrm{H}), 2.95(\mathrm{~d}, \mathrm{~J}=5.0 \mathrm{~Hz}, 1 \mathrm{H})$, 3.12 (d, J = 5.0 Hz, 1H), 4.56 (d, J = 15.0 Hz, 1H), 4.84 (d, J = 15.0 Hz, 1H), 6.89-7.41 (m, 3H), $8.00(\mathrm{~s}, 1 \mathrm{H}), 8.53(\mathrm{~s}, 1 \mathrm{H})$.

2-(2',4'-Difluorophenyl)-2-(1H-1-imidazolylmethyl)oxirane (2d). A 50\% aqueous solution of $\mathrm{NaOH}$ (3 mL, $37.5 \mathrm{mmol})$ was slowly added to a stirred solution of $\mathbf{1 d}(0.89 \mathrm{~g}, 4.0 \mathrm{mmol})$ and methyl trimethylsulfonium sulfate $(0.98 \mathrm{~g}, 5.2 \mathrm{mmol})$ in dichloromethane $(6 \mathrm{~mL})$. The mixture was heated under reflux for $24 \mathrm{~h}$. Water was added $(30 \mathrm{~mL})$ and it was extracted with dichloromethane. The organic phase was dried with anhydrous sodium sulfate and the solvent was evaporated to afford $2 \mathbf{d}^{17}(0.802 \mathrm{~g}, 84 \%)$ as a red oil; ${ }^{1} \mathrm{H}$ NMR $\left(\mathrm{CDCl}_{3}\right) \delta 2.82(\mathrm{~d}, \mathrm{~J}=4.4$ Hz, 1H), 2.90 (d, J = 4.4 Hz, 1H), 4.09 (d, J = 15.0 Hz, 1H), 4.60 (d, J = $15.0 \mathrm{~Hz}, 1 \mathrm{H}), 6.77$ (m, 2H), 6.87 (s, 1H), 6.94 (s, 1H), 6.97 (m, 1H), 7.35 (s, 1H); MS m/z: 236 (M+32), 208 (22), 167 (12), 153 (32), 140 (28), 127 (100), 119 (27), 81 (39). 
2-(2'-Fluorophenyl)-2-[1-(1H-1-imidazolyl)ethyl]oxirane (2e). A 50\% aqueous solution of $\mathrm{NaOH}$ (2 mL, $25 \mathrm{mmol})$ was slowly added to a stirred solution of $\mathbf{1 e}(0.58 \mathrm{~g}, 2.6 \mathrm{mmol})$ and methyl trimethylsulfonium sulfate $(0.67 \mathrm{~g}, 3.5 \mathrm{mmol})$ in dichloromethane $(5 \mathrm{~mL})$. The mixture was heated under reflux for $24 \mathrm{~h}$. Water was added $(10 \mathrm{~mL})$ and it was extracted with dichloromethane. The organic phase was dried with anhydrous sodium sulfate and the solvent was evaporated to afford $2 \mathbf{e}$ as a mixture of two diastereoisomers $\left(0.29 \mathrm{~g}, 49 \%\right.$, ratio $1.4 / 1$ by ${ }^{1} \mathrm{H}$ NMR); the mixture was not further purified and it was used directly in the next step; IR (film, $\mathrm{cm}^{-1}$ ) 3114, 2990, 1492, 1452, 1265, 1227, 1080, 846, 742; MS m/z: 231 (M+1, 39), 217 (9), 202 (12), 163 (10), 149 (17), 137 (22), 123 (29), 109 (92), 95 (100), 68 (28); diastereoisomer A: ${ }^{1} \mathrm{H}$ NMR $\left(\mathrm{CDCl}_{3}\right) \delta 1.51$ (d, J = 7.0 Hz, 3H), $2.50(\mathrm{~d}, \mathrm{~J}=4.4 \mathrm{~Hz}, 1 \mathrm{H}), 2.72$ (d, J = 4.4 Hz, 1H), 4.57 (q, J = 7.0 Hz, 1H), 6.88-7.31 (m, 6H), $7.48(\mathrm{~s}, 1 \mathrm{H})$; diastereoisomer B: ${ }^{1} \mathrm{H}$ NMR $\left(\mathrm{CDCl}_{3}\right) \delta 1.48$ (d, J = 7.3 Hz, 3H), 2.80 (d, J = 5.0 Hz, 1H), 3.10 (d, J = 5.0 Hz, 1H), 5.27 (q, J = $7.3 \mathrm{~Hz}, 1 \mathrm{H})$, 6.88-7.31 (m, 7H).

2-(2'-Fluoro-4'-methoxyphenyl)-2-(1H-1-imidazolylmethyl)oxirane (2f). A 50\% aqueous solution of $\mathrm{NaOH}(5 \mathrm{~mL}, 62.5 \mathrm{mmol})$ was slowly added to a stirred solution of $\mathbf{1 f}$ (1.52 g, 6.5 $\mathrm{mmol})$ and trimethylsulfoxonium iodide $(1.94 \mathrm{~g}, 8.8 \mathrm{mmol})$ in dichloromethane $(10 \mathrm{~mL})$. The mixture was heated under reflux for $16 \mathrm{~h}$. Water was added $(50 \mathrm{~mL})$ and it was extracted with dichloromethane. The organic phase was dried with anhydrous sodium sulfate and the solvent was evaporated to afford $\mathbf{2 f}$ (1.61 g, 99\%) as a red oil; it was not further purified and it was used directly in the next step; ${ }^{1} \mathrm{H}$ NMR $\left(\mathrm{CDCl}_{3}\right) \delta 2.81(\mathrm{~d}, \mathrm{~J}=5.1 \mathrm{~Hz}, 1 \mathrm{H}), 2.86(\mathrm{~d}, \mathrm{~J}=5.1 \mathrm{~Hz}, 1 \mathrm{H})$, 3.68 (s, 3H), 4.08 (d, J = 14.6 Hz, 1H), 4.56 (d, J = 14.6 Hz, 1H), 6.5-6.6 (m, 2H), 6.8 (s, 1H), $6.9(\mathrm{~s}, 1 \mathrm{H}), 7.01(\mathrm{~m}, 1 \mathrm{H}), 7.34(\mathrm{~s}, 1 \mathrm{H})$.

2-(2'-Fluoro-5'-trifluoromethylphenyl)-2-(1H-1-imidazolylmethyl)oxirane (2g). A 50\% aqueous solution of $\mathrm{NaOH}(7 \mathrm{~mL}, 87.5 \mathrm{mmol})$ was slowly added to a stirred solution of $\mathbf{1 g}(2.44$ g, $8.9 \mathrm{mmol}$ ) and methyl trimethylsulfonium sulfate (2.73 g, $14.5 \mathrm{mmol})$ in dichloromethane (15 $\mathrm{mL}$ ). The mixture was heated under reflux for $24 \mathrm{~h}$. Water was added (30 $\mathrm{mL})$ and it was extracted with dichloromethane. The organic phase was dried with anhydrous sodium sulfate and the solvent was evaporated to afford a red oil (2.21 g) in which the presence of $\mathbf{2} \mathbf{g}$ was identified by ${ }^{1} \mathrm{H}$ NMR, but no defined compound could be obtained after column chromatography of the residue; ${ }^{1} \mathrm{H}$ NMR $\left(\mathrm{CD}_{3} \mathrm{OD}\right) \delta 3.13(\mathrm{~d}, \mathrm{~J}=5.0 \mathrm{~Hz}, 1 \mathrm{H}), 3.31$ (d, J = 5.0 Hz, 1H), 4.47 (d, J = 14.6 Hz, 1H), 4.99 (d, J = 14.6 Hz, 1H), 7.08 (s, 1H), 7.24 (s, 1H), 7.41-7.65 (m, 2H), 7.69 (s, 1H), 7.85-7.96 (m, 1H).

2-(2',4'-Difluorophenyl)-2-[1-(1H-1,2,4-triazol-1-yl)ethyl]oxirane (2h). A 50\% aqueous solution of $\mathrm{NaOH}(3.6 \mathrm{~mL}, 48.0 \mathrm{mmol})$ was slowly added to a stirred solution of $\mathbf{1 h}(1.11 \mathrm{~g}, 4.7$ $\mathrm{mmol})$ and methyl trimethylsulfonium sulfate $(1.44 \mathrm{~g}, 7.7 \mathrm{mmol})$ in dichloromethane $(8 \mathrm{~mL})$. The mixture was heated under reflux for $12 \mathrm{~h}$. Water was added (20 mL) and it was extracted with dichloromethane. The organic phase was dried with anhydrous sodium sulfate and the solvent was evaporated to afford $2 \mathbf{h}^{13 a, 18}$ as a mixture of diastereoisomers $(0.568 \mathrm{~g}, 49 \%)$, ratio 2.5/1 by ${ }^{1} \mathrm{H}$ NMR) as a yellow oil; the mixture was not further purified and it was used directly in the next step; IR (film, $\mathrm{cm}^{-1}$ ) 3114, 3078, 3001, 2945, 1618, 1600, 1505, 1427, 1274, 1142, 
1087, 965, 952, 677, 558, 440, 416; MS m/z: 251 (M+ 8), 236 (48), 182 (15), 155 (45), 127 (100); major diastereoisomer: ${ }^{1} \mathrm{H}$ NMR $\left(\mathrm{CDCl}_{3}\right) \delta 1.56(\mathrm{~d}, \mathrm{~J}=7.3 \mathrm{~Hz}, 3 \mathrm{H}), 2.60(\mathrm{~d}, \mathrm{~J}=4.4 \mathrm{~Hz}$, 1H), 2.75 (d, J = 4.4 Hz, 1H), 4.86 (q, J = 7.3 Hz, 1H), 6.79-6.68 (m, 3H), 7.86 (s, 1H), 8.06 (s, $1 \mathrm{H})$; minor diastereoisomer: ${ }^{1} \mathrm{H}$ NMR $\left(\mathrm{CDCl}_{3}\right) \delta 1.54(\mathrm{~d}, \mathrm{~J}=7.3 \mathrm{~Hz}, 3 \mathrm{H}), 2.80(\mathrm{~d}, \mathrm{~J}=4.4 \mathrm{~Hz}$, 1H), 3.12 (d, J = 4.4 Hz, 1H), 4.86 (q, J = 7.3 Hz, 1H), 6.81-7.07 (m, 3H), 7.79 (s, 1H), 7.98 (s, $1 \mathrm{H})$.

2-(2'-Fluorophenyl)-2-[1-(1H-1,2,4-triazol-1-yl)ethyl]oxirane (2i). A 50\% aqueous solution of $\mathrm{NaOH}$ (11 mL, $136.9 \mathrm{mmol}$ ) was slowly added to a stirred solution of $\mathbf{1 i}$ (2.55 g, $11.6 \mathrm{mmol})$ and trimethylsulfoxonium iodide (3.54 g, $16.1 \mathrm{mmol}$ ) in dichloromethane (20 mL). The mixture was heated under reflux for $24 \mathrm{~h}$. Water was added $(25 \mathrm{~mL})$ and it was extracted with dichloromethane. The organic phase was dried with anhydrous sodium sulfate and the solvent was evaporated to afford $2 \mathbf{i}$ as a mixture of diastereoisomers $(2.71 \mathrm{~g}, 98 \%)$, ratio $13 / 1$ by ${ }^{1} \mathrm{H}$ NMR) as a red oil; the mixture was not further purified and it was used directly in the next step; IR (film, cm ${ }^{-1}$ ) 2993, 1503, 1493, 1453, 1275, 1215, 1205, 781; MS m/z: 251 (M+, 8), 236 (48), 182 (15), 155 (45), 127 (100); major diastereoisomer: ${ }^{1} \mathrm{H}$ NMR $\left(\mathrm{CDCl}_{3}\right) \delta 1.37$ (d, J = $7.3 \mathrm{~Hz}$, 3H), 2.40 (d, J = 5.0 Hz, 1H), 2.56 (d, J = 5.0 Hz, 1H), 4.76 (q, J = 7.3 Hz, 1H), 6.80-6.90 (m, 3H), 6.93-7.14 (m, 1H), $7.84(\mathrm{~s}, 1 \mathrm{H}), 7.92(\mathrm{~s}, 1 \mathrm{H})$; major diastereoisomer: ${ }^{13} \mathrm{C} \mathrm{NMR}\left(\mathrm{CDCl}_{3}\right) \delta$ 14.8, 51.2, 58.2, 114.8 (d, J = 20.2 Hz), 122.9 (d, J = 14.7 Hz), 123.8 (d, J = 3.7 Hz), 126.7, 128.7 (d, J = 3.7 Hz), 142.3, 150.6, 159.7 (d, J = 246.3 Hz).

2-(2'-Fluoro-5'-trifluoromethylphenyl)-2-[1-(1H-1,2,4-triazol-1-yl)ethyl]oxirane (2j). A 50\% aqueous solution of $\mathrm{NaOH}(8 \mathrm{~mL}, 112.2 \mathrm{mmol}$ ) was slowly added to a stirred solution of $\mathbf{1 j}$ (2.96 g, $10.3 \mathrm{mmol})$, trimethylsulfoxonium iodide (2.57 g, $10.9 \mathrm{mmol})$ and benzyltrimethylammonium chloride in dichloromethane $(16 \mathrm{~mL})$. The mixture was heated under reflux for $24 \mathrm{~h}$. Water was added $(25 \mathrm{~mL})$ and it was extracted with dichloromethane. The organic phase was extracted with $1 \mathrm{M} \mathrm{HCl}(4 \times 10 \mathrm{~mL})$. The aqueous phase was neutralized with a saturated aqueous solution of sodium carbonate and extracted with dichloromethane. The organic phase was dried with anhydrous sodium sulfate and the solvent was evaporated to yield $2 \mathbf{j}$ ( $1.57 \mathrm{~g}, 51 \%$ ) as a red oil; it was not further purified and it was used directly in the next step; IR (film, $\mathrm{cm}^{-1}$ ) 1624, 1601, 1504, 1383, 1329, 1270, 1229, 1206, 1167, 1124, 1094, 1074, 1005, 833; ${ }^{1} \mathrm{H}$ NMR $\left(\mathrm{CDCl}_{3}\right) \delta$ 1.57 (d, J = 7.3 Hz, 3H), 2.50 (d, J = 5.0 Hz, 1H), 2.75 (d, J = 5.0 Hz, 1H), 4.98 (q, J = 7.3 Hz, 1H), 7.12 (dd, J = 10.9, 8.8 Hz, 1H), 7.42 (d, J = 5.8 Hz, 1H), 7.57 (m, 1H), 7.87 (s, 1H), 8.08 (s, 1H); MS m/z: 301 (M+21), 286 (52), 232 (18), 205 (45), 177 (100), 127 (19), 96 (40).

6-Chloro-3-(1H-1,2,4-triazol-1-ylmethyl)benzo[b]furan (3a). A solution of sodium tertbutoxide (0.53 g, $5.4 \mathrm{mmol})$ in anhydrous DMSO $(4 \mathrm{~mL})$ was added at RT and under an inert atmosphere to a stirred solution of the methanesulfonate of $\mathbf{2 a}(1.00 \mathrm{~g}, 2.7 \mathrm{mmol})$ in anhydrous DMSO (10 mL). After stirring the mixture at RT for $24 \mathrm{~h}$, water was added $(20 \mathrm{~mL})$ and it was extracted with dichloromethane. The organic phase was washed with water, it was dried with anhydrous sodium sulfate and the solvent was evaporated, affording a red oil (0.58 g), which was chromatographed through silica gel with ethyl acetate as eluent. Compound 3a was eluted first (0.112 $\mathrm{g}, 18 \%)$, and then a mixture of isomers 4 (0.098 g, 13\%, ratio $E / Z 13 / 1$ by ${ }^{1} \mathrm{H}$ NMR). 
Compound 3a: mp 75-77º (diethyl ether); IR (film, $\mathrm{cm}^{-1}$ ) 3116, 1575, 1504, 1470, 1424, 1271, 1134, 1103, 1013, 810; ${ }^{1} \mathrm{H}$ NMR $\left(\mathrm{CDCl}_{3}\right) \delta 5.23(\mathrm{~s}, 2 \mathrm{H}), 7.21$ (d, J = 8.1 Hz, 1H), 7.36 (d, J = $8.1 \mathrm{~Hz}, 1 \mathrm{H}), 7.50(\mathrm{~s}, 1 \mathrm{H}), 7.69(\mathrm{~s}, 1 \mathrm{H}), 7.96(\mathrm{~s}, 1 \mathrm{H}), 8.08(\mathrm{~s}, 1 \mathrm{H}) ;{ }^{13} \mathrm{C} \mathrm{NMR}\left(\mathrm{CDCl}_{3}\right) \delta 43.9$, 112.8, 115.2, 120.5, 124.5, 125.1, 131.7, 143.3, 144.7, 152.5, 156.0; MS m/z: 235 (22), 233 (M , 64), 208 (26), 206 (85), 167 (32), 165 (100), 102 (52), 75 (27); $\mathrm{C}_{11} \mathrm{H}_{8} \mathrm{ClN}_{3} \mathrm{O}$ : calcd. C 56.54, H 3.45, N 17.89; found C 56.71, H 3.71, N 17.21. Compound 4 (mixture of isomers): ); IR (film, $\mathrm{cm}^{-1}$ ) 3366, 3123, 2922, 1586, 1507, 1475, 1279, 1136, 1101, 516, 453; ${ }^{1} \mathrm{H}$ NMR $\left(\mathrm{CDCl}_{3}\right)$ (major isomer) $\delta 4.56(\mathrm{~s}, 2 \mathrm{H}), 7.15(\mathrm{~d}, \mathrm{~J}=8.1 \mathrm{~Hz}, 1 \mathrm{H}), 7.27(\mathrm{~s}, 1 \mathrm{H}), 7.32(\mathrm{~d}, \mathrm{~J}=8.1 \mathrm{~Hz}, 1 \mathrm{H}), 7.52$ (s, 1H), 7.63 (s, 1H), 7.88 (s, 1H); MS m/z: 271 (M+1), 236 (32), 234 (100), 170 (10).

6-Fluoro-3-(1H-1,2,4-triazol-1-ylmethyl)benzo[b]furan (3c). A solution of sodium tertbutoxide (2.54 g, $25.6 \mathrm{mmol})$ in anhydrous DMSO (8 $\mathrm{mL})$ was added at RT and under an inert atmosphere to a stirred solution of 2c (4.55 g, $19.2 \mathrm{mmol})$ in anhydrous DMSO (30 mL). After stirring the mixture at RT for $24 \mathrm{~h}$, water was added $(50 \mathrm{~mL})$ and it was extracted with dichloromethane. The organic phase was washed with water, it was dried with anhydrous sodium sulfate and the solvent was evaporated, affording 3c (2.52 g, 64\%) as a red oil. It was purified by column chromatography through silica gel with dichloromethane/ethyl acetate 4:1 as eluent. Compound 3c was obtained as a white solid (2.38 g, 61\%); mp 66-67 ${ }^{\circ} \mathrm{C}$ (cyclohexane); IR ( $\mathrm{KBr}$, $\left.\mathrm{cm}^{-1}\right)$ 3090, 1622, 1568, 1512, 1489, 1264, 1165, 1091, 1019, 943, 842, 815; ${ }^{1} \mathrm{H} \mathrm{NMR}\left(\mathrm{CDCl}_{3}\right) \delta$ 5.46 (s, 2H), 7.02 (apparent td, J = 8.5, 2.2 Hz, 1H), 7.23 (dd, J = 5.8, 3.6 Hz, 1H), 7.38 (dd, J = 8.7, $5.1 \mathrm{~Hz}, 1 \mathrm{H}), 7.71$ (s, $1 \mathrm{H}), 7.98(\mathrm{~s}, 1 \mathrm{H}), 8.08$ (s, 1H); ${ }^{13} \mathrm{C} \mathrm{NMR}\left(\mathrm{CDCl}_{3}\right) \delta$ 43.6, 99.4, 99.9, 111.6, 112.0, 119.9, 120.0, 142.9, 144.2, 152.1, 161.3 (d, J = 242.6 Hz); MS m/z: $217\left(\mathrm{M}^{+}, 51\right)$, 190 (61), 149 (100), 101 (57), 95 (11), 75 (22); $\mathrm{C}_{11} \mathrm{H}_{8} \mathrm{FN}_{3} \mathrm{O}$ : calcd. C 60.83, H 3.71, N 19.35; found C 60.73, H 3.74, N 19.33.

3-[1-(1H-1-Imidazolyl)ethyl]benzo[b]furan (3e). A solution of sodium tert-butoxide (0.15 g, $1.5 \mathrm{mmol})$ in anhydrous DMSO (2 mL) was added at RT and under an inert atmosphere to a stirred solution of $\mathbf{2 e}(0.29 \mathrm{~g}, 1.3 \mathrm{mmol})$ in anhydrous DMSO $(3 \mathrm{~mL})$. After stirring the mixture at RT for $24 \mathrm{~h}$ and at $60^{\circ} \mathrm{C}$ for $48 \mathrm{~h}$, water was added $(10 \mathrm{~mL})$ and it was extracted with dichloromethane. The organic phase was washed with water and with a saturated $\mathrm{NaCl}$ aqueous solution, it was dried with anhydrous sodium sulfate and the solvent was evaporated. The residue was purified by column chromatography through silica gel with mixtures of dichloromethane/ethyl acetate of increasing polarity as eluent. Compound 3e was obtained as an oil (0.055 g, 16\%); ${ }^{1} \mathrm{H}$ NMR $\left(\mathrm{CDCl}_{3}\right) \delta 1.89$ (d, J = $\left.7.3 \mathrm{~Hz}, 3 \mathrm{H}\right), 5.54$ (q, J = 7.3 Hz, 1H), 6.937.61 (m, 8H); MS m/z: $212\left(\mathrm{M}^{+}, 20\right), 145$ (100), 118 (24), 115 (31), 91 (12); HRMS Calcd. $\mathrm{C}_{13} \mathrm{H}_{12} \mathrm{~N}_{2} \mathrm{O}: 212.0949$, Found: 212.0953.

6-Methoxy-3-(1H-1-imidazolylmethyl)benzo[b]furan (3f). A solution of sodium tert-butoxide (0.12 g, $1.2 \mathrm{mmol})$ in anhydrous DMSO $(2 \mathrm{~mL})$ was added at RT and an under inert atmosphere to a stirred solution of $\mathbf{2 f}(0.207 \mathrm{~g}, 0.8 \mathrm{mmol})$ in anhydrous DMSO $(3 \mathrm{~mL})$. After stirring the mixture at RT for $24 \mathrm{~h}$ and at $60^{\circ} \mathrm{C}$ for $24 \mathrm{~h}$, water was added $(10 \mathrm{~mL})$ and it was extracted with dichloromethane. The organic phase was washed with water and with a saturated $\mathrm{NaCl}$ aqueous solution, it was dried with anhydrous sodium sulfate and the solvent was evaporated. The residue (0.105 g, red oil) was purified by column chromatography through silica gel with mixtures of 
dichloromethane/ethyl acetate of increasing polarity as eluent. Compound $\mathbf{3 f}$ was obtained as an oil (0.032 g, 17\%); ${ }^{1} \mathrm{H}$ NMR $\left(\mathrm{CDCl}_{3}\right) \delta 3.70$ (s, 3H), 5.11 (s, 2H), 6.34-7.51 (m, 7H); MS m/z: 228 (M , 40), 213 (2), 161 (11), 145 (100), 133 (6), 117 (5); HRMS Calcd. $\mathrm{C}_{13} \mathrm{H}_{12} \mathrm{~N}_{2} \mathrm{O}_{2}$ : 228.0898, Found: 228.0940.

6-Fluoro-3-[1-(1H-1,2,4-triazol-1-yl)ethyl]benzo[b]furan (3h). A solution of sodium tertbutoxide (0.19 g, $2.04 \mathrm{mmol})$ in anhydrous DMSO (2 mL) was added at RT and under an inert atmosphere to a stirred solution of $\mathbf{2 h}(0.350 \mathrm{~g}, 1.4 \mathrm{mmol})$ in anhydrous DMSO $(6 \mathrm{~mL})$. After stirring the mixture at RT for $24 \mathrm{~h}$ and at $60^{\circ} \mathrm{C}$ for $20 \mathrm{~h}$, water was added $(20 \mathrm{~mL})$ and it was extracted with dichloromethane. The organic phase was washed with water and with a saturated $\mathrm{NaCl}$ aqueous solution, it was dried with anhydrous sodium sulfate and the solvent was evaporated. The residue ( $0.315 \mathrm{~g}$, red oil) was purified by column chromatography through silica gel with ethyl acetate as eluent. Compound 3h was obtained as an oil (0.053 g, 18\%); IR (film, $\mathrm{cm}^{-1}$ ) 3121, 2994, 2931, 1618, 1490, 1437, 1276, 1138, 807; ${ }^{1} \mathrm{H}$ NMR $\left(\mathrm{CDCl}_{3}\right) \delta 1.95$ (d, J = 7.0 Hz, 3H), 5.75 (q, J = 7.0 Hz, 1H), 6.76 (apparent td, J = 8.8, 2.2 Hz, 1H), 7.15-7.23 (m, 2H), 7.64 (s, 1H), 7.95 (s, 1H), $8.05(\mathrm{~s}, 1 \mathrm{H}) ;{ }^{13} \mathrm{C} \mathrm{NMR}\left(\mathrm{CDCl}_{3}\right) \delta 20.4,51.7,99.4,99.8,111.5,111.9$, 120.0, 143.1, 151.7, 155.6, 161.2 (d, J = 242.6 Hz); MS m/z: 231 (M+, 6), 162 (100), 134 (19), 115 (7); HRMS Calcd. $\mathrm{C}_{12} \mathrm{H}_{10} \mathrm{FN}_{3} \mathrm{O}$ : 231.0807; Found: 231.0804.

5-Trifluoromethyl-3-[1-(1H-1,2,4-triazol-1-yl)ethyl]benzo[b]furan (3j). A solution of sodium tert-butoxide $(0.20 \mathrm{~g}, 2.1 \mathrm{mmol})$ in anhydrous DMSO $(2 \mathrm{~mL})$ was added at RT and under an inert atmosphere to a stirred solution of $\mathbf{2} \mathbf{j}(0.520 \mathrm{~g}, 1.8 \mathrm{mmol})$ in anhydrous DMSO $(3 \mathrm{~mL})$. After stirring the mixture at RT for $24 \mathrm{~h}$, water was added $(10 \mathrm{~mL})$ and it was extracted with dichloromethane. The organic phase was washed with water and with a saturated $\mathrm{NaCl}$ aqueous solution, it was dried with anhydrous sodium sulfate and the solvent was evaporated. The residue (0.359 g, red oil) was purified by column chromatography through silica gel with mixtures of dichloromethane/ethyl acetate of increasing polarity as eluent. Compound $\mathbf{3 j}$ was obtained as an oil (0.027 g, 54\%); IR (film, $\mathrm{cm}^{-1}$ ) 3114, 2938, 1496, 1328, 1124; ${ }^{1} \mathrm{H}$ NMR $\left(\mathrm{CDCl}_{3}\right) \delta 1.98$ (d, J = $6.6 \mathrm{~Hz}, 3 \mathrm{H}), 5.79(\mathrm{q}, \mathrm{J}=6.6 \mathrm{~Hz}, 1 \mathrm{H}), 7.55(\mathrm{~s}, 2 \mathrm{H}), 7.63(\mathrm{~s}, 1 \mathrm{H}), 7.73(\mathrm{~s}, 1 \mathrm{H}), 7.96(\mathrm{~s}, 1 \mathrm{H}), 8.05$ (s, 1H); ${ }^{13} \mathrm{C} \mathrm{NMR}\left(\mathrm{CDCl}_{3}\right) \delta$ 20.6, 51.5, 112.5, 117.6, 120.7, 122.5, 125.7, 127.5, 144.2, 152.0;

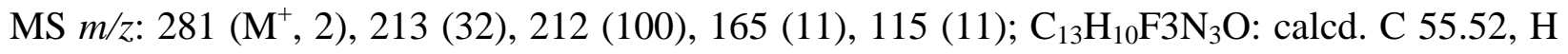
3.58, N 14.94; found C 55.25, H 3.99, N 13.81.

\section{Acknowledgements}

Financial support from Ministry of Science and Technology (then Ministry of Education and Science) of Spain (Projects 2002BQU-04002 and CTQ-2005-01254/BQU, predoctoral scholarship to A. S.), Generalitat de Catalunya (Projects 2001SGR00181 and 2005SGR00305), and Universitat Autònoma de Barcelona (Project PNL2005-10) is gratefully acknowledged. 


\section{References and Footnotes}

1. Friedriichsen, W. Furanes and their Benzo Derivatives: Synthesis. In Comprehensive Heterocyclic Chemistry II; Katritzky, A. R.; Rees, C. W.; Scriven, E. F. V., Eds.; Pergamon: Oxford, 1996; Vol. 2, Chapter 7.

2. (a) Beak, P.; Reitz, D. B. Chem. Rev. 1978, 78, 275. (b) Beak, P.; Zajdel, W. J.; Reitz, D. B. Chem. Rev. 1984, 84, 471. (c) Cuberes, M. R.; Moreno-Mañas, M.; Trius, A. Synthesis 1985, 302. (d) Shimizu, S.; Ogata, M. J. Org. Chem. 1986, 51, 3897. (e) Shimizu, S.; Ogata, M. J. Org. Chem. 1987, 52, 2314. (f) Shimizu, S.; Ogata, M. Tetrahedron 1989, 45, 637. (g) Moreno-Mañas, M.; Bassa, J.; N. Lladó; Pleixats, R. J. Heterocycl. Chem. 1990, 27, 673.

3. (a) Boyle, F. T. Eur. Pat. Appl 122,693, 1984. (b) Y. Arredondo, Ph. D. thesis, Universitat Autònoma de Barcelona, 1996.

4. Godefroi, E.; Heeres, J.; Van Cutsem, J. J. Med. Chem. 1969, 12, 784.

5. (a) Hurd, R. E.; John, B. K. J. Magn. Reson. 1991, 91, 648. (b) Parella, T.; SánchezFerrando, F.; Virgili, A. J. Magn. Reson. 1995, 112, 241.

6. (a) Astleford, B. A.; Goe, G. L.; Keay, J. G.; Scriven, E. F. V. J. Org. Chem. 1989, 54, 731.

(b) Katjár-Peredy, M.; Bauer, L. J. Heterocycl. Chem. 1997, 34, 637.

7. (a) Akgün, E.; Glinski, M.; Dhawan, K.; Durst, T. J. Org. Chem. 1981, 46, 2730. (b) Gololobov, Y., Nesmeyanov, A.; Lysenko, V.; Boldeskul, I. Tetrahedron 1987, 42, 2609.

8. Mosset, P.; Grée, R. Synth. Commun. 1985, 15, 749.

9. (a) Schwesinger, R.; Hasenfratz, C.; Schlemper, H.; Walz, L.; Peters, E. M.; Peters, K.; Von Schnering, H. Angew. Chem. Int. Ed. 1993, 32, 1361. (b) Tang, J.; Dopke, J.; Verkade, J. G. J. Am. Chem. Soc. 1993, 115, 5015.

10. Narayanan, A.; Chapman, D. R.; Upadhyaya, S. P.; Bauer, L. J. Heterocycl. Chem. 1993, 30, 1405.

11. (a) Teixidó, M.; Ph.D. Thesis, Universitat Autònoma de Barcelona 1992. (b) Sledzinski, B; Cieslak, L.; Zawadzki, M. Pol. Organika 1979, 1. Chem. Abstr. 94, 83719.

12. Chapman, D. R.; Bauer, L. J. Heterocycl. Chem. 1990, 27, 2053

13. (a) Itoh, K.; Okonogi, K. Eur. Pat. Appl. EP0421210, 1991; Chem. Abstr.115, 92271. (b) Richardson, K.; Gymer, G. E. Eur. Pat. Appl. EP0153803, 1985; Chem. Abstr. 104, 109650. (c) Richardson, K.; Gymer, G. E. Eur. Pat. Appl. EP0118245, 1984; Chem. Abstr. 102, 45953.

14. Kalendra, D. M.; Sickles, B. R. J. Org. Chem. 2003, 68, 1594.

15. Moreno-Mañas, M.; Arredondo, Y.; Pleixats, R.; Teixidó, M.; Raga, M. M.; Palacín, C.; Castelló, J. M.; Ortiz, J. A. J. Heterocyclic Chem. 1992, 29, 1557.

16. Richardson, K., Brit. UK Pat. Appl. 2,099,818, 1982; Chem. Abstr. 99, 38467.

17. Babin, D.; Weston, J. PCT Int. Appl. WO02090350, 2002; Chem. Abstr. 137, 353032.

18. Richardson, K.; Narayanaswami, S. Eur. Pat. Appl. EP0122056, 1984; Chem. Abstr. 102, 132042. 